\title{
AGROTURISZTIKAI LEHETŐSÉGEK IZLANDON ÉS NORVÉGIÁBAN SZOLGÁLTATÁSLOGISZTIKAI NÉZŐPONTBÓL
}

\author{
Gál József - Mucsi Imre - Palotás János
}

\begin{abstract}
Absztrakt: Két északi ország, amelyek távol esnek hazánktól, mégis érdekes turisztikai célpontként tüntek fel a közelmúltban. Ennek oka elérhetőségének egyszerübbé válása, melyben a széles tömegek számára elérhető árú repülőjegyeket kínáló diszkont légitársaságok szerepe meghatározó. Ezzel egyidöben felmerül annak kérdése is, milyen típusú turizmus lehet elönyös, illetve fenntartható Izlandon és Norvégiában? A választ az országok turisztikai attrakcióinak vonzerejében, azok ismertségében, illetve az adott desztináció más értékeiben kell keresni. Ilyen a helyi természeti értékekre alapozott mezőgazdaság és annak terményeire épülő feldolgozóüzemek, mint kisgazdaságok. Fontos, hogy a fenntarthatóság érdekében az oktatás különböző szintjein megtörténjen a tudatformálás, és mind a fogadó fél, mind az érkező turisták tisztában legyenek a célállomás szemléletével, elvárásaival.
\end{abstract}

Abstract: Two northern countries that are far away from our country have nevertheless been seen as an interesting tourist destination recently. This is why it is easier to reach the availability of discount airlines offering cheap flights to large masses. At the same time, this question arises, what kind of tourism can be beneficial, and sustainable in Iceland and Norway? The answer is to attract the attractions of the country's tourist attractions, their acquaintance, and other values of other destinations. Such is the local agriculture based on natural values and its crops based on processing plants as small farms. It is important that awareness-raising takes place at different levels of education for sustainability and both the host party and the arriving tourists are aware of the destination's expectations and expectations.

Kulcsszavak: Izland, Norvégia, agroturizmus, logisztika, oktatás

Keywords: Iceland, Norway; agro-tourism, logistics, education

\section{Bevezetés}

2017. május-június fordulóján, illetve augusztusban a Tudás Alapítvány sikeres pályázata lehetőséget biztosított egy kisebb szakértői csoport számára két skandináv országban tapasztalatokat szerezni. A projekt izlandi koordinátora az Izlandi Turisztikai Kutató Központ (Icelandic Tourism Research Centre) volt az északizlandi Akureyri városából. A programok szervezésében közremüködött a Hólari Egyetem (Hólar University College) és az Akureyri Egyetem (University of Akureyri) is. Norvégiában a Høgskulen for landbruk og bygdeutvikling - HLB (Mezőgazdasági és Vidékfejlesztési Főiskola) közremüködésével valósult meg tanulmányút, ahol a fỏ szakmai célok hasonlóak voltak:

- a fenntartható, a természeti értékeket megörizve bemutató turizmus megismerése, kapcsolatépítés;

- együttmüködés kialakítása az izlandi és norvég partnerekkel, új projektek tervezése, előkészítése (EGT Alap, Erasmus+ stb.);

- ismerkedés a falusi (vidéki) turizmus izlandi gyakorlatával, oktatási helyszíneivel, módszereivel, infrastrukturális és személyi feltételeivel; 
- a falusi turizmus jól müködő helyszíneinek meglátogatása mindkét országban (farmok, vendéglátóhelyek, termékelőállító helyek stb.);

- ezen turisztikai formához kapcsolódó logisztikai megoldások megismerése.

$\mathrm{Az}$ északi példa - előreláthatóan - teljes egészében nem adaptálható, több elemében, szemléletében viszont érdeklődésre tarthat számot. Kiemelendő, hogy a minőségi turizmushoz infrastruktúra kell. Ahhoz, hogy az infrastruktúra képes legyen megfelelő színvonalon kiszolgálni a turizmust, elengedhetetlenek az alapvető beruházások. Ezen túl hasznos mérni az ezekkel való elégedettségi szintet is (Zsótér et al., 2014).

Az infrastruktúra egyfajta logisztikai redszer, de az nem zavarhatja magát a vonzerőt jelentő értéket, és merni kell limitálni a turisták számát. Fontos, hogy a szolgáltatást nyújtók ne legyenek ösztönözve - egy határon túl - az anyagi bevétel fokozására, illetve felkészítsék őket az elvárt példamutatásra, szemlélet közvetítésre, amely kihat a turisták viselkedésére is, így a közös cél megvalósulhat.

\section{Anyag és módszer}

A meglátogatott két országgal kapcsolatban számos szakirodalom áll rendelkezésre, amelyek ismertetésére jelen tanulmányban meghaladná a terjedelmi korlátokat. Az alábbiakban csupán néhány rövid, célirányos bemutatás és példa kerül leírásra.

\subsection{Izland és Norvégia a szakirodalom tuikrében}

Izland hasonló nagyságú ország, mint Magyarország, viszont lakossága csupán töredéke a miénknek, elhelyezkedése pedig perifériális (Rowland, 2007). Turistaforgalma eléri a milliós nagyságrendet évente, ami a lakosság háromszorosát is meghaladja, így komoly dilemmát jelent számukra az elönyök és a hátrányok széles körben elfogadható arányainak egyensúlyban tartása. Izland továbbra is az ökoturizmusra teszi a hangsúlyt, magas áraival szüri a beutazó tömeget, egyúttal törekszik arra, hogy színvonalas élményben legyen részük a turistáknak. A magyarországi gyakorlat mennyiségi szemléletü, tömegturizmust preferál, a bevétel maximalizálására, míg az izlandi megközelítés a minőségi, a természetet megőrző, profitmaximalizáló célfüggvényre törekszik. Természetesen a turizmus sem ítélhető meg feketén-fehéren, itt is az arányokon van a hangsúly. A lehetőségeket értelmesen kihasználó formák lehetnek a fenntartható turizmus alapjai.

Norvégia viszont egy nagy területü ország, túlnyomó részét a Skandinávhegység borítja. Fjordokkal és szigetek ezreivel erősen tagolt partvonala több mint $25000 \mathrm{~km}$ hosszú. Az országot keleten $2542 \mathrm{~km}$-es szárazföldi határ választja el Svédországtól, Finnországtól és Oroszországtól. Nyugatról és délröl a Norvégtenger, az Északi-tenger és a Skagerrak-tengerszoros, északról pedig a Barentstenger határolja. A Golf-áramlatnak köszönhetően a szélességi fokon szokásosnál magasabb a hőmérséklet és több a csapadék, föként a partvidéken. A négy évszak egyértelmüen elkülönül; a belsö területeken kevesebb a csapadék, és hidegebbek a telek. Az ország északi része szubarktikus, míg a Spitzbergák sarkvidéki éghajlatú. A napsütéses órák száma évszakonként jelentősen eltér. Az északi sarkkörön túli területeken a nyári nap le sem nyugszik (innen ered az „éjféli nap országa” kifejezés), 
de a délebbi területeken is mintegy napi 20 órán át tart a világosság. Télen viszont fordított a helyzet. A látogatás során Bergen és Kleppstasjon, melyek az ország délnyugati részén találhatók, illetve Stavanger és környéke volt az úticél (Németh, 2001).

A földrajzi elhelyezkedés perifériális jellege logisztikai szempontból is kihívást jelent. Az anyagáramlás - beleértve a turisták mozgatását is - új, szabályozott megoldásokat követel, mivel kívül esik a fő európai áramlatokon. Izland esetében további nehézség, hogy egy szigetről van szó, amely csak tengeren vagy légi úton közelíthető meg. Az ország középső része lakatlan, a hegyekben nincsenek járható utak a gleccsereken, és vasútvonal egyáltalán nem épült ki. Norvégiában is leginkább csak a déli országrészben vannak vasútvonalak, az utak kiépítettsége (kapacitása) észak felé haladva egyre kisebb. A fjordokkal erősen tagolt partvidék jelentős többletkilométer-futást eredményezhet, így a kompközlekedésnek országon belül is jelentős szerepe van. Az információáramlás logisztikája magas színvonalon megoldottnak tekinthető, hiszen Norvégiában található a telekommunikáció egyik világszínvonalú cégének központja. Az oktatás rendszerén keresztül kaphatunk képet a tudásáramlás logisztikájáról. Ez az egyik legfontosabb innovatív tényező e két országban.

\subsection{Néhány izlandi példa}

Kaffikú (http://kaffiku.is/2017.10.10.) tehenészeti telep és kávézó (1. ábra). A modern állattartás és a természetesség együttes megjelenésének jó példája a meglátogatott telep. Izland kis létszámú lakossága és annak egyenetlen megoszlása, továbbá a vidéki területek - esetenként - nehéz megközelíthetősége az állattartást is átformálta. Egyrészt nagy hangsúlyt kap a külterjesség, ahol megoldható (pl. húshasznú tehenészet), másrészt viszont a munkaerő hiánya, a korszerü technika és technológia alkalmazását hívta megoldásnak a tejhasznú tehenészet esetében, ahol az állatokat naponta többször fejni kell, és a takarmányozásban is másra helyeződik a hangsúly.

\section{1. ábra: Kaffikú tehenészeti telep és kávézó (Izland)}

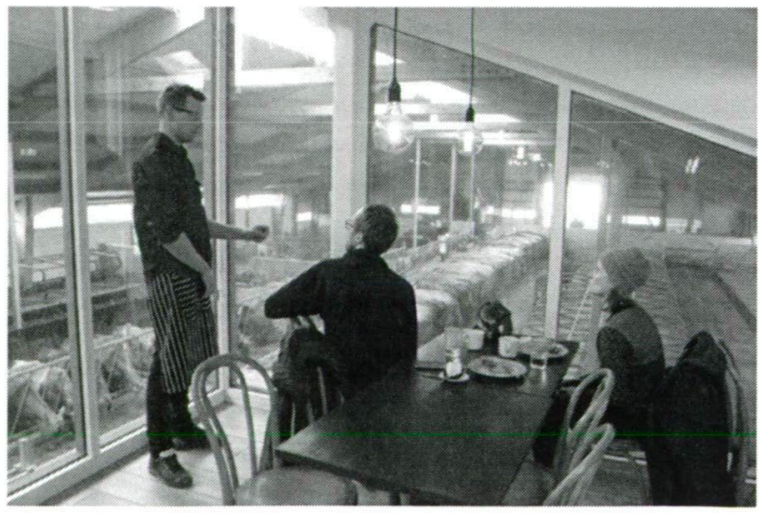

Forrás: szerzői felvétel (2017) 
Egy ember szolgált ki több száz tehenet, az automata rendszerek (pl. chipes azonosítású tehenek, automata fejögép), robot trágyaeltávolító gép. Újszerü és figyelemre méltó, hogy az állatgondozó szakma milyen új tartalmakkal bővül. Mindenképp szükségessé válik széleskörübb felhasználói szintű informatikai készség, önálló munkavégre alkalmasság és anyagmozgatógép kezelési ismerete. Ezen kompetenciák elsajátítására részben az iskolapadban, részben pedig a 'learning by doing' módszertan alkalmazásával nyílik Izlandon hatékony megoldás.

Lýtingsstaðir lótenyésztéssel és -tartással foglalkozó gazdaság, Icelandic Horse History Centre (2. ábra) (http://www.lythorse.com/?lang=en2017.10.10.). Érdekes dilemma az állat-egészségügyi biztonság és a fejlődés kérdése (nem csupán lovak esetében). Az izlandi ló genetikailag nem keveredhet a szigeten kívüli egyedekkel, így a külföldi versenyekről sem térhetnek vissza a lovak Izland területére. Másrészt viszont bizonyos paraméterek ma már nem tartoznak a világ élvonalába, így meggondolandó e zártság feloldása - ellenőrzött körülmények között - a belterjesség elkerülése érdekében.

\section{2. ábra: Lýtingsstaðir lovasfarm (Izland)}

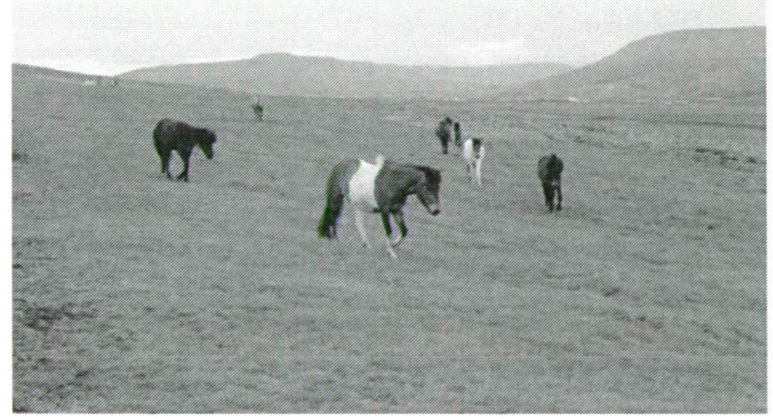

Forrás: szerzői felvétel (2017)

\subsection{Néhány norvégiai példa}

Huset ved Havet („Ház a tenger mellett”) Varhaug-ban. Az ökoturizmus kiváló példája a tengertől 400 m-re található ház egész évben nyitva áll a szállást keresők számára. A 200 éves, felújított falusi ház minden kényelemmel felszerelt szobákkal rendelkezik.

A közelben található látnivalók, turista-elfoglaltságok: séta a tengerparton, horgászás a közeli folyóban (lazac) vagy tengerparton, madár les, golfozás stb.

Grødaland/Nærbø (3. ábra) a régió egyik leglátványosabb és legjobban megőrzött múzeumi együttese, mely 17. és 18 . századi épületekből álló halászfarmot mutat be a látogatók számára. A két lakóházban látható kiállítás bemutatja, hogyan éltek a Jæren vidéki halászok 1850 körül és az 1900-as évek elején. Május és szeptember között számos tematikus napot szerveznek, amikor az érdeklődők 
tevékenyen részt vehetnek különböző élelmiszerek előállításában, vagy a gazdaság területén végezhetnek egyéb hagyományos tevékenységeket.

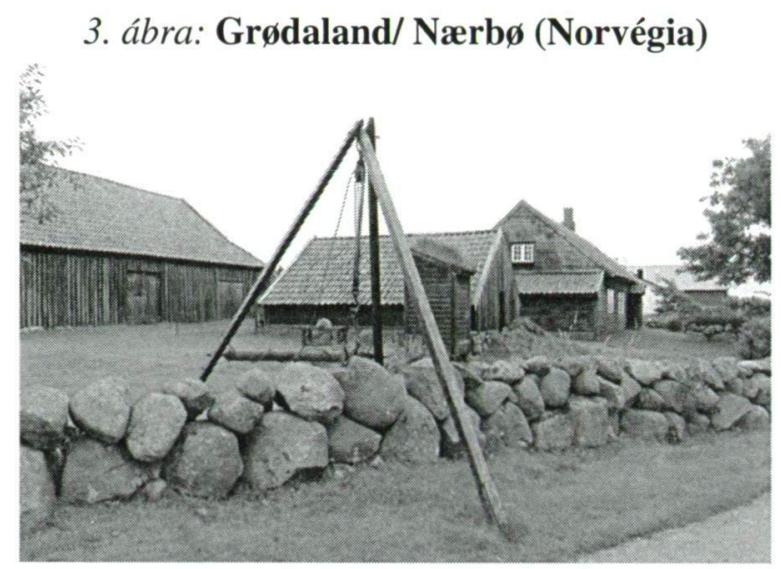

Forrás: szerzői felvétel (2017)

A bemutatott példák csupán kiragadott töredékét képezik a vizsgálat szempontjából értelmezhető és hasznosítható lehetőségeknek, viszont rávilágítanak arra, hogy olyan helyszínekből - nem csupán természeti - értékekre épülnek.

\section{Turisztikai-szolgáltatáslogisztikai eredmények és értékelésük}

Izland és Norvégia turizmusának és szolgáltatáslogisztikájának tanulmányozása közben számos érdekes, gyakran követendőnek tekinthető példa kerül felsorolásra a teljesség igénye nélkül:

- Izlandon a turizmus kutatási központja vidéken, a turisztikailag kevésbé feltárt és kiaknázott területen található. Akureyri, a sziget második legnagyobb városa, az északi parton fekszik, oktatási, kereskedelmi és dinamikusan fejlődő turisztikai központ, így alkalmas ellenpólusa a Reykjavík és az ,arany körút” (Pingvelliri Nemzeti Park, Gullfoss, Geysir) déli turisztikai paradicsomának. Nagyon szimpatikus, hogy térben is ott kutatnak, ahol a fejlesztendő potenciál van, ahol a helyismeret jelentős hozzáadott értéket képvisel. Logisztikai szempontból így válik kétpólusúvá Izland, ezen hub müködtetésével.

- A Hólari Egyetem (Holár University College) egy azonos nevű, nagyon kicsi településen található. Püspöki központ a kereszténység megjelenése óta, aminek - elsősorban - szimbolikus jelentősége van. Hólarban több az izlandi ló, mint a lakosság, mégis nyüzsgő diáktelepüléssé válik évről évre. A vidékfejlesztés céljaival összhangban a felsőoktatási intézménynek nem feltétlenül nagyvárosban kell lennie, viszont színvonalas müködtetéséhez a feltételeket biztosítani kell.

- Az oktatás különböző szintjein egyre fontosabb, hogy a hallgatók, tanulók szakmai tapasztalatot szerezzenek más szakmai és kulturális környezetben. 
Ennek érdekében eredményes előkészítő megbeszéléseket folytattunk két oktatási intézményben és a Hey Iceland farmereket egyesítő szakmai szervezettel. A „learning by doing”-módszertan kiválóan alkalmas az agrárturisztikai ismeretek hatékony gyakorlati elsajátítására. Ehhez a korábban említett nemzetközi programok támogatást nyújtanak.

- Izlandon tett látogatásunk során néhány meglepőnek tünő, mégis ott természetes jelenségre lettünk figyelmesek. A gazdák - a közös cél érdekében - együttmüködnek, előzetesen megosztják a feladatokat, bemutatókat egymás között, és ajánlják a másikat (bár nem lenne feltétlenül feladatuk), a szomszédról pozitívan és szépen beszélnek. A legkisebb tanyán is lehet bankkártyával fizetni, mindennek megvan a maga ára, és ez így természetes.

- Egy vidéki, falusi turisztikai helyszín - a sziget településszerkezete egyenlőtlen és ritka - megismertetéséhez szervezés szükséges. Véletlenszerüen nem találnak rá a turisták a látnivalókra, illetve tudni kell azt is, hogy miért lehet vonzó egy-egy helyszín? Mást szeretne egy gazdálkodásba bekapcsolódni vágyó, pl. juh- és kecskeállomány esetén, illetve a speciális izlandi lóval foglalkozni kívánó látogató (https://www.northiceland.is/en/what-to-see-do/service/the-icelandichorse-history-centre2017.10.10.). Az agroturizmus is egyfajta szolgáltatóként olyan mértékben és mélységben engedi be a látogatót a folyamatokba, ami számára vonzó, de egyúttal nem jár indokolatlanul nagy higiéniai vagy más kockázattal (pl. kávézó a szarvasmarha-istálló felett). Az itt felsoroltak kiváló példái az ismeret eljuttatásának, logisztikájának.

- Elismerésre méltó az izlandiak állatszeretete, a lovak intenzív bevonása a turizmusba. A lovas turizmus Magyarországon is egyre jobban hódít, de közel sem éri el az izlandi népszerüségét (Zsótér, 2006). Az agroturizmus komplex fejlődését bizonyítja, hogy a bemutatófarmok többsége szálláslehetőséget is biztosit. A keresett farmokat könnyü megtalálni, mert jó az információs rendszer, illetve könnyen elsajátítható az útszámozás. Az utazások során a látnivalókat - egységes rendszerben - előjelzőkkel és helyileg is jelölik.

- Izland lakosságának döntő többsége délnyugaton, Reykjavíkban és környékén lakik. Ez a helyzet aszimmetriát jelent, ami a sziget turisztikai terhelését néha a teherbírás felettivé billenti, más esetben pedig a kapacitások kihasználatlanságát okozza. Érdekes megfigyelni, hogyan népszerüsítik, illetve terelik a nagyszámú látogatót Észak-Izland irányába, illetve ösztönzik őket a vendégéjszakák számának növelésére.

- Izland felkészült az egész országra kiterjedő turistaáradat fogadására (pl. mindenkitöl lehet angol nyelven információt szerezni, mindenkivel lehet angol nyelven kommunikálni). Gyorsan javul a két és három számjegyü utak simasága és burkolata. A vidéki szállások felszereltsége is magas komfortfokozatot biztosít a vendégek számára. 
- Izland mind a turisták, mind a szakemberek érdeklődésének központjába került az utóbbi években, mutatja ezt az is, hogy a július-augusztusi fö turistaszezon előtt és után is egyre több érdeklődő utazik a szigetországba. Az eljutás komphajókkal is lehetséges - teszik ezt egyre többen lakóautókkal, de a nagy távolság miatt időigényes, így a turisták számára a repülöjáratok vonzóbbak. Az elmúlt néhány évben a diszkont légitársaságok számára is egyre vonzóbbá vált Izland és Norvégia is. A Keflavik repülötér kapacitása még rendelkezik tartalékokkal így a szabályozott járatfrekvenciafejlesztés meg tud valósulni. A belföldi járatok - egy másik repülőtérről - a fövárosból közlekednek kis és közepes méretü repülögépekkel. Ez turisztikai-logisztikai szempontból nem számottevő. Norvégiában pedig sürün vannak repülöterek, amelyek eddig a belföldi forgalmat szolgálták ki, viszont most már jónéhány bekapcsolódott a nemzetközi forgalomba, és fogad járatokat, ezzel is egyenletesebbé teszi a turisztikai terhelést (itt a vendégmunkások áramlása is számottevő tényezö Kelet-Európa irányába és vissza).

- Szakmai szempontból érdekes azon a norvégiai dilemmán elgondolkozni, hogy mikor jelent nagyobb értéket egy olyan képződmény, mint a Preikestolen (magyarul:

„szószék-szikla”) (https://www.visitnorway.com/listings/preikestolen/185743/2017.10.10.). Egyik nézöpont szerint, ha kiépítetté teszik, akkor - jelenleg ingyenesen látogatható - pénzt lehet szedni meglátogatásáért, az odajutásért, szuvenírbolt és étterem, kávézó telepíthető az útvonalra, ezáltal komoly bevételi forrássá válik a nagyszámú turista miatt. A másik alternatíva a természet védelme, a turizmus korlátozása, legalább is nem ösztönzése az ilyen típusú helyekre.

- A HLB (Høgskulen for Landbruk og Bygdeutvikling) a „Tudást a fejlesztésért" mottót választotta. Ez azt jelenti, hogy a HLB az előállított, fejlesztett ismeretet és terjesztett tudást - lehetöség szerint - közvetlenül a helyi/regionális vállalkozói és fejlesztési folyamatokban kívánja felhasználni, felhasználtatni. Az elmúlt néhány évben a HLB Skandináviában a vidékfejlesztés vezető tudományos tényezőjévé fejlődött.

- A HLB esetében kiemelendő, hogy a képzőhely földrajzi pozicionálása nagyon fontos szempont volt. Magyarországon szinte elképzelhetetlen, hogy egy felsőoktatási intézmény gyakorlatilag egy faluba teszi a székhelyét, illetve bátran költözik oda, ahol képzésére szükség van (most is éppen költözés êlött állnak).

- A gyakorlatorientáltság nagyon fontos, és ott tud megvalósulni, ahol a feladat jelentkezik. A hallgatók számára olyan környékbeli gazdaságokat keresnek (és fizetnek is érte), akik hajlandóak innovatív megoldásokat bevezetni, fejleszteni, továbbá gyakorlati képzőhelyként is müködni. A gazdaságok részéről is megjelenik több előny. Hozzájutnak olyan ismerethez, tudáshoz, gyakorlathoz, amelyet - mondhatni - 
kockázatmentesen (anyagilag is) megkapnak, ha pedig beválik, akkor folytathatják profitorientált tevékenységükben is.

A példák sora hosszan folytatható. Tanulságos az a fejlödési ív, amelyet megterveztek és hatékonyan megvalósítanak. Az anyagi folyamatok áramlása mellet a tudásáramlás logisztikai ötvözetet képez, amely alkalmas arra, hogy lehetőségeket nyújtson, és egyúttal ésszerüen korlátozzon.

\section{4.Összegzés}

Érdekesség - és elgondolkodtató gyakorlat - lehet számunkra is az a norvég példa, hogy a klimatikus, így a mezőgazdasági tevékenység szempontjából holtidőkre időzítik kurzusaikat, tanfolyamaikat nagy intenzitással. A képzési portfóliót a környékbeli lakosság, gazdálkodók, igények és lehetőségek is jelentősen formálják. Mivel Norvégia nem EU-tagország, a bolognai rendszer sem úgy kötelező rájuk nézve, mint ránk, továbbá az irányító hatóság is jelentős szabadságot ad számukra, a minőség és az eladhatóság több piaci elemet is tartalmaz. Itt az elsajátított tudás, a megszerzett gyakorlat és a versenyszféra pozitív visszajelzése a legfontosabb. Természetesen a bizonyítvány, a diploma fontos, viszont az ismeret, a tudás, illetve annak minél gyorsabban a gyakorlatban történő hatékony alkalmazhatósága a meghatározó. Ez a fajta rugalmasság nálunk még elképzelhetetlen.

Izland turizmusának dinamikus növekedése szemléletbeli változást kíván. Az ökoturizmus - mint különlegesen forma - egy bizonyos látogatószám felett már nem biztosítható, viszont a sziget területének nagysága és a természeti attrakciók rurális területeken való megtalálhatósága alkalmas arra, hogy térben és időben széthúzható legyen a forgalom. Izland és Magyarország sok tekintetben hasonló adottságokkal rendelkezik (pl. termálenergia), látnivalók sokasága és sokszínüsége, viszont a földrajzi elhelyezkedés és a történelmi múlt különbözősége lehetőséget biztosít arra, hogy más karakterü turizmus kialakítása során érjünk el sikereket, viszont több izlandi turizmus-módszertani elem jól adaptálható.

\section{Köszönetnyilvánítás}

EGT finanszírozási mechanizmus - ösztöndíj program szakmai grants látogatások (M1), HU08-0056-M1-2016 sz. és HU08-0081-M1-2016 sz. projekt.

\section{Irodalomjegyzék}

Kaffi kú. <http://kaffiku.is/> (2017.10.10.)

Lýtingsstaðir - The Old Stable: Horse and heritage. <http://www.lythorse.com/?lang=en> (2017.10.10.)

Németh A. (2001): Norvégia. Panoráma országkalauzok. Medicina Könyvkiadó Zrt. Budapest.

Preikestolen <https://www.visitnorway.com/listings/preikestolen/185743/> (2017.10.10.)

Rowland, M. (2007): Izland. Booklands $2000 \mathrm{Kft}$. Békéscsaba.

The Icelandic Horse History Centre. <https://www.northiceland.is/en/what-to-see-do/service/theicelandic-horse-history-centre> (2017.10.10.)

Zsótér B. (2006): Turizmus Mezöhegyesen: a Hotel Nonius bemutatása. In: Gál J. (szerk.) Európai Uniós Kutatási és Oktatási Projektek Napja és Leonardo da Vinci Learn at Work Projekt- 
találkozó [European Union Research and Educational Projects Day and Leonardo da Vinci Learn at Work Project Meeting]. Hódmezővásárhely, Magyarország, Hódmezővásárhely: Delfin Computer Informatikai Zrt., Paper CD, 6.

Zsótér B., Schmidt A., Trandafir N. (2014): Research of statisfaction related to investments (20062010) accomplished by the local council in Sandorfalva for durable development Quaestus: Open Access Journal 5 (3): 107-114. 